\section{Infra-Red Spectra of Silica}

AN experimental investigation of the infra-red absorption of transparent silica between $1 \cdot 0$ and $7 \cdot 5 \mu$ has resulted in the correction and extension of existing data, with the consequent possibility of formulating a set of vibration frequencies which appear to have more significance than those hitherto put forward. Pending detailed publication it may be useful to summarise some of the results.

Absorption coefficients and wave-lengths have been measured using a wide range of thicknesses of fused silica and crystalline quartz and a considerable improvement in both accuracy and resolution has been effected. Many new bands have been found in crystalline quartz; on the other hand, one recorded by Plyler ${ }^{1}$ at $2 \cdot 72 \mu$ was definitely absent, as were also several bands reported by Parlin ${ }^{2}$ in fused silica between 2 and $4 \mu$. Another of these, near $2.73 \mu$ (Drummond), shows such markedly different intensities in different specimens that it is unlikely that it is due to silica at all. There are grounds for attributing it to dissolved $\mathrm{CO}_{2}$.

TABLE 1.

\begin{tabular}{|c|c|c|c|c|}
\hline & $\begin{array}{l}\text { Total } \\
\text { No. of } \\
\text { bands }\end{array}$ & $\begin{array}{l}\text { No. ascribable } \\
\text { to harmonics }\end{array}$ & $\begin{array}{l}\text { No. ascribable } \\
\text { to combinations }\end{array}$ & $\begin{array}{l}\text { No. of } \\
\text { bands } \\
\text { omitted }\end{array}$ \\
\hline Fused Silica & 14 & 11 & - & 3 \\
\hline Quartz $(\omega)$ & 38 & 18 & 10 & 10 \\
\hline Quartz $(\varepsilon)$ & 29 & 14 & 8 & 7 \\
\hline
\end{tabular}

The absorption spectra of fused silica and of the ordinary and extraordinary rays in quartz have been examined. That of fused silica is the simplest, and of fourteen bands, eleven can be fairly well represented as harmonics of five frequencies. (Two very weak bands and that at $2 \cdot 73 \mu$ are omitted.)

The spectra of quartz are more complex, but bands corresponding to those of fused silica can be picked out, the associated five frequencies deduced and further bands ascribed to additional harmonies and combinations. The numbers of bands included in this scheme are indicated in Table 1.

TABue 2.

(Frequencies are in $\mathrm{cm}^{-1}$; * indicates reflection measurements)

\begin{tabular}{|l|c|c|c|c|c|}
\hline & $v_{1}$ & $v_{2}$ & $v_{3}$ & $v_{4}$ & $v_{s}$ \\
\hline Fused Silica & 1120 & 935 & 799 & 746 & 659 \\
Quartz $(\omega)$ & 1129 & 937 & 797 & 751 & 663 \\
Quartz $(\varepsilon)$ & 1131 & 932 & 800 & 751 & 666 \\
\hline
\end{tabular}

\begin{tabular}{|c|c|c|c|c|}
\hline $\begin{array}{cc}\nu_{x}-\nu_{5} & \text { (Fused) } \\
", & (\omega) \\
", & (t)\end{array}$ & $\begin{array}{l}461 \\
466 \\
465\end{array}$ & $\begin{array}{l}276 \\
274 \\
266\end{array}$ & $\begin{array}{l}14 \overline{0} \\
134 \\
134\end{array}$ & $\begin{array}{l}87 \\
88 \\
85\end{array}$ \\
\hline $\begin{array}{l}\text { Raman } \\
\text { Effect }\end{array}\left\{\begin{array}{l}\text { Fused) } \\
\text { (Crystalline) }\end{array}\right.$ & $\begin{array}{c}444 ; 500 \\
464\end{array}$ & $\begin{array}{l}263 \\
265\end{array}$ & $\stackrel{?}{126}$ & $\stackrel{?}{85}$ \\
\hline $\begin{array}{l}\text { Far } \\
\text { Infra- } \\
\text { red }\end{array}$ & $\begin{array}{l}472^{*} \\
476^{*} \\
507^{*}\end{array}$ & $\begin{array}{c}? \\
263 \\
?\end{array}$ & $\begin{array}{c}116 \\
130 \\
?\end{array}$ & $95 \stackrel{85}{;} ?^{82}$ \\
\hline
\end{tabular}

There are several simple numerical relationships between these five frequencies (for example, $2 v_{1}=3 v_{4} ; \quad v_{2}=2 v_{1}-2 v_{5} ; \quad 2 v_{2}=v_{2}+v_{5}$; $\left.4 v_{2}=5 v_{4} ; 5 v_{3}=6 v_{5}\right)$, and they may, therefore, not be true fundamentals but be themselves formed from a simpler set of frequencies. Each of them, however, occurs in an independent harmonic series in the observed absorption spectra.

These quasi-fundamentals are, further, related to the far infra-red spectrum ${ }^{3}$ and to the Raman effect 4 as may be seen by taking differences between $\nu_{5}$ and each of the others. This relationship is set out in Table 2.

Physics Department,

D. G. DRUMmond.

Armstrong College,

Newcastle-on-Tyne.

1 Plyler, Phys. Rev., 33, 48; 1929.

' Parlin, Phys. Rev., 34, 81; 1929. Lecomte, "Le Spectre Infra"Barnes, Phys. Reo.

rouge", pp. $145-6$. Gross and Romanova, Z. phys., 55, 744; 1929. Menzies, Phil.
Mag., 8, 504 ; 1929 .

\section{Synthesis of Ascorbic Acid (Vitamin C) by means of Tissues in Vitro}

The Tillmans technique of titration against the indicator 2:6-dichlorophenol indophenol has been modified by Harris and Ray $^{1}$ for the estimation of ascorbic acid in trichloroacetic acid extracts of different materials. By employing the same method, slightly modified by the introduction of glacial acetic acid before titration ${ }^{2}$, we have been for some time investigating the nature of the precursor and mechanism involved in the synthesis of ascorbic acid by the rat, a species known to be independent of an external source of the vitamin.

The production of ascorbic acid by means of the liver, kidney and spleen tissues of the rat from glucose, fructose, galactose, mannose, arabinose and xylose has been studied. The minced tissues $(0 \cdot 2 \mathrm{gm}$.) were incubated at $37^{\circ}$ in phosphate buffer of $p \mathrm{H} 7 \cdot 4$ (5 c.c.) or in a mixture of the phosphate buffer (2 c.c.) and Ringer-Locke solution (3 c.c.) for 3 hours with and without the different sugars $(20 \mathrm{mgm}$.$) . Rather$ unexpected results were obtained, as will be seen from the following table, which gives average figures. Mannose appears to be almost unique among the sugars investigated in being converted into ascorbic acid by all these tissues under the stated conditions, and the amount of ascorbic acid formed is significant. The values obtained with the other sugars appear to be within the range of individual variations.

Ascorbic Acid (mgm.)

formed per gm. tissue after incubation with sugar.

$\begin{array}{lccc} & \text { Spleen } & \text { Kidney } & \text { Liver } \\ \text { Glucose } & -0.025 & -0.036 & -0.107 \\ \text { Fructose } & -0.050 & \pm 0.075 & -0.130 \\ \text { Galactose } & 0 & -0.050 & -0.060 \\ \text { Mannose } & +0.350 & +0.320 & \pm 0.300 \\ \text { Arabinose } & -0.010 & +0.040 & -0.038 \\ \text { Xylose } & -0.022 & +0.010 & +0.025\end{array}$

The mechanism concerned in the dehydrogenation of mannose into ascorbic acid is under investigation. It is interesting to note that Ray $^{3}$ has, meanwhile, observed that in pea-seedlings mannose has a remarkable influence on the formation of ascorbic acid. This would indicate a similarity between the mechanisms involved in the above transformation occurring in the animal and plant tissues investigated.

Biochemical Laboratory,

B. C. GuHa.

Bengal Chemical and

A. R. GHosh.

Pharmaceutical Works, Ltd. Calcutta.

Oct. 6.

1 Harris and Ray, Biochem. J., 27, 303 ; 1933.

Guha and Gosh, Current Science, 2, 390 ; 1934

- Ray, Biochem. J., 28, 996 ; 1934. 